\title{
ТИПОМОРФИЗМ ПИРИТОВ ОЛЬХОВСКО-ЧИБИЖЕКСКОГО ЗОЛОТОРУДНОГО ПОЛЯ (ВОСТОЧнЫЙ САЯН)
}

\author{
Пшеничкин Анатолий Яковлевич', \\ paya@tpu.ru \\ Гаврилов Роман Юрьевич', \\ GavrilovRY@tpu.ru
' Национальный исследовательский Томский политехнический университет, Россия, 634050, г. Томск, пр. Ленина, 30.

Актуальность работы вызвана необходимостью комплексного минералого-геохимического изучения золоторудных месторождений для создания прогнозно-поисковых моделей рудных объектов.

Цель: изучение типоморфных свойств пирита (кристалломорфологии, элементов-примесей, термо-эдс) из разнотемпературных минеральных ассоциаций и генераций рудных тел и околорудных метасоматитов золоторудных месторождений Ольховско-Чибижекского рудного поля.

Методы: кристалломорфология, термо-эдс, статистическая обработка геохимических данных, пространственное моделирование типоморфных свойств пирита.

Результаты. Типоморфные свойства пирита - кристалломорфология, элементы-примеси, термо-эдс - закономерно изменяются в объёме рудных тел месторождений Ольховско-Чибижекского рудного поля и от ранних высокотемпературных минеральных ассоциаций к заключительным этапам формирования месторождений. Пириты месторождений рудного поля представлены в основном кристаллами кубического габитуса, количество кристаллов которого закономерно уменьшается с запада на восток (и волнообразно с глубиной рудных тел с амплитудой волны $200 . .240$ м) от Лысогорского к Медвежьему и Константиновскому месторождениям. Наибольшая комбинационная устойчивость кристаллов пирита у $\{100\}+\{210\},\{100\}+\{210\}+\{111\}$, а на Лысогорском месторождении - $\{100\}+\{321\}$ (более 50 \%), где грань $\{321\}$ в комбинациях кристаллов слабо развита и характерна для низкотемпературных минеральных ассоциаций и верхних частей рудных тел. Пириты рудных тел месторождений обогащены $\mathrm{Ag}, \mathrm{Pb}$, $\mathrm{Zn}, \mathrm{Pt}$, As и особенно Au, весьма характерных для многих золоторудных объектов Сибири и других регионов. При этом в пиритах верхних частей рудных зон и надрудных ореолов содержатся повышенные концентрации $\mathrm{Ag}, \mathrm{Ba}, \mathrm{Sb}, \mathrm{Hg}$, а пириты средних частей рудных тел и рудных столбов резко обогащены Au, Ag, Cu, Pb, Zn, Bi, Pt, в прикорневых участках и в местах их выклинивания по простиранию и падению в пиритах накапливаются Ni, Co, U, нередко As. Впервые в пиритах месторождений рудного поля и эфелях Ольховской обогатительной фабрики выявлены повышенные концентрации Рt и Pd. Пириты рудных тел и околорудных метасоматитов месторождений рудного поля имеют преобладающую электронную (Константиновское), электронно-дырочную (Медвежье) или дырочную (Лысогорское) проводимость. С глубиной рудных тел и с запада на восток рудного поля от Лысогорского к Медвежьему и Константиновскому месторождениям закономерно увеличивается электронный тип проводимости пиритов как из продуктивных минеральных ассоциаций, так и из околорудных метасоматитов. На основании выявленных типоморфных признаков пиритов: кристалломорфологии, элементов-примесей и термо-эдс, закономерно изменяющиеся в пространстве и во времени, можно судить об уровне эрозионного среза рудных тел и месторождений, их перспективности на глубину и фланги. Минералогическое картирование по пириту на золото необходимо проводить (в комплексе с другими методами исследования) на всех стадиях геологоразведочных работ.

\section{Ключевые слова:}

Золотое оруденение, пирит, кристалломорфология, термо-эдс, элементы-примеси.

\section{Введение}

Изучение типоморфных свойств отдельных минералов: кристалломорфологии, химического состава, термо-эдс и др., проводилось разными исследователями на многочисленных объектах [1-5]. В последнее десятилетие был обобщен обширный материал по типоморфным свойствам пирита золоторудных и других типов месторождений и получены новые данные, в основу которых легли прецизионные аналитические исследования [6, 7].

Неоднократно было замечено, что ряд минералов, обладающих определенными типоморфными свойствами, занимают закономерное положение в объеме рудно-минерализованных зон золоторудных месторождений [8-17]. Наиболее информативными их представителями являются сульфидные минералы: пирит, арсенопирит, пирротин, реже другие минералы. Пирит является наиболее распространенным минералом, который образуется как при эндогенных, так и при экзогенных процессах, в том числе в процессе гидротермально-метасоматического рудообразования. В связи с чем его типоморфные свойства, в отличии от других рудных минералов, изучены более детально [18-20].

Изучение типоморфных свойств пирита злоторудных месторождений позволяет, в комплексе с другими методами исследования, определять уровень эрозионного среза оруденения, реконструировать условия рудообразования и, в конечном итоге, прогнозировать оруденение на флангах и глубоких горизонтах рудных тел и месторождений.

Детальным изучением Ольховско-Чибижекского рудного района в 80-90 гг. прошлого века занимался коллектив исследователей Томского политехнического института (ныне университета) под руководством профессора А.Ф. Коробейникова. Данное исследование является продолжением той кропотливой многолетней работы, фактиче- 
ский материал которой не был до конца обработан и опубликован.

\section{Геологическое строение рудного поля}

Геологическое строение и структурная позиция Ольховско-Чибижекского рудного поля подробно описаны во многих публикациях [21-23 и др.].

Ольховско-Чибижекский золоторудный район Восточного Саяна размещается в Кизир-Казырской структурно-формационной зоне (рис. 1). На северо-востоке она имеет тектонический контакт с байкалидами Дербинской СФЗ, на западе ограничена девонским Минусинским межгорным прогибом, на юго-западе по Кандатскому глубинному разлому граничит со структурами Западного Саяна. Для региона типичен двухъярусный геологический разрез: нижний ярус представлен нижнекембрийскими карбонатными толщами, а верхний - вулканогенно-терригенными образованиями нижнего палеозоя. Многочисленные выходы гранитоидов относятся к формации нижнепалеозойских батолитов «пестрого» состава [24]. Главной структурой района является Артёмовская мегантиклиналь. Это устойчивое внутри геосинклинальное поднятие с карбонатным типом разреза. $K$ центральной части этой мегантиклинали приурочен Шиндинский гранитоидный плутон $\left(\epsilon_{3}-0\right)$ ольховского диорит-гранодиорит-гранитного комплекса, с которым парагенетически связано золотое оруденение.

В приконтактовой северной зоне Шиндинского нижнепалеозойского плутона размещены золотоносные магнезиально-известковые скарны, контактово-метасоматические золото-медносульфидные залежи и кварц-золото-полисульфидные жилы и штокверки. Общая рудно-метасоматическая золотоносная зона, шириной 5 км и протяженностью свыше 30 км, охватывает приконтактовые части плутона в нижнекембрийских карбонатных толщах. Рудное поле занимает западную часть Артёмовской мегантиклинали с южным сочленением Кизирской антиклинали, а на западе ограничено краевой зоной Минусинского прогиба. Вдоль северного замыкания Шиндинского плутона проходит крупный Ольховский разлом, контролирующий размещение золоторудных объектов (рис. 1).

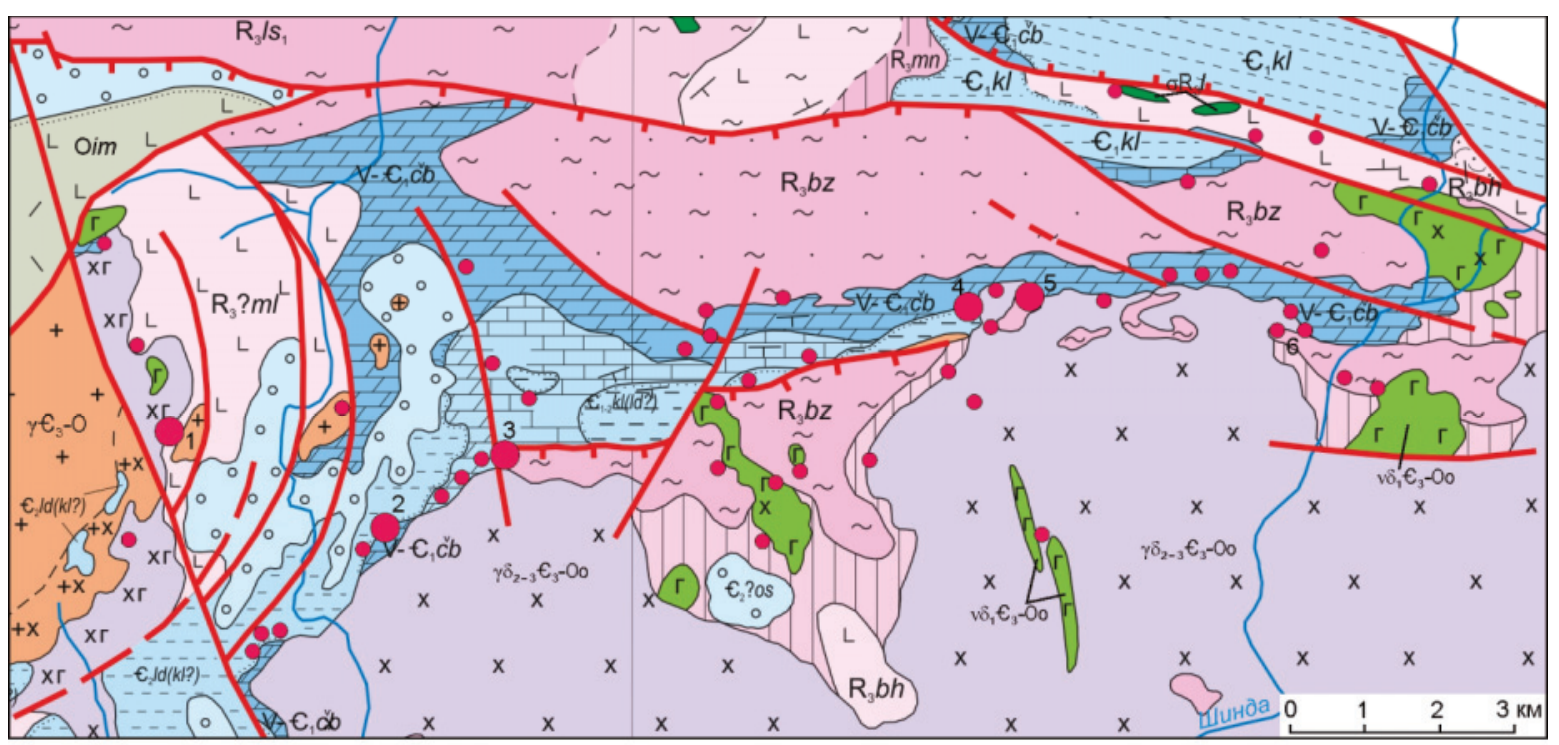

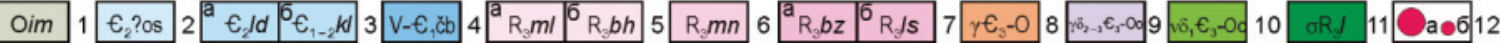

Pис.1. Схематическая геологическая карта Ольховско-Чибижекского рудного поля по [25]: 1-7 - вулканогенно-осадочные формации: 1 - трахибазальт-трахиандезит-трахириолитовая (имирская свита); 2 - вулканогенно-туфогенно-терригенная (осиновская свита); 3 - терригенно-рифокарбонатная (а - лодочная, б - колпинская свиты); 4 - известково-доломитовая (чибижекская свита); 5 - метариолит-метабазальтовая (а - малиновская, б - бахтинская); 6 - черносланцево-карбонатная (манская свита); 7 - позднерифейские: а) туфогенно-терригенная молассоидная (безымянская свита), б) вулканогенно-карбонатно-сланцевая (лысанская свита); 8-11- интрузивные комплексы: 8- буеджульский (?) и беллыкский (?) гранитоидный; 9, 10 - ольховский габбро-диорит-гранодиоритовый: 9 - вторая и третья фазы; 10 - первая фаза; 11 - лысанский дунит-клинопироксенит-габбровый; 12 - месторождения и рудопроявления золота (1 - Лысогорское, 2 - Медвежье, 3 - Ольховское, 4 - Константиновское, 5 - Торчинское, 6 - Каратавское)

Fig. 1. Schematic geological map of Olkhovsko-Chibizhek ore field (according to V.V. Bezzubtsev, I.N. Dyatlova, 2011): 1-7 volcanogenic-sedimentary formations: 1 - trachybasalt-trachyandesite-trachyriolithic (Imir suite); 2 - volcanogenic-tuffogenic-terrigenous (aspen suite); 3 - terrigenous-rifocarbonate (a - lodochnaya, $\sigma$ - Kolpinskaya suites); 4 - calc-dolomite (Chibizhke suite); 5 - metariolite-metabasalt (a - Malinovskaya, б-Bakhtinskaya); 6 - black shale-carbonate (manna suite); 7 - Late Riphean: a) tuffogenic-terrigenous molassoid (Bezymyanskaya Formation), б) volcanogenic-carbonate-schist (Lysansky Formation); 8-11 - intrusive complexes: 8- buyezhul (?) and bellyksky (?) granitoid; 9,10 - olkhovsky gabbro-diorite-granodiorite: 9 - the second and third phases; 10 - the first phase; 11 - Lysansky dunite-clinopyroxenite-gabbro; 12 - deposits and ore occurrences of gold (1 - Lysogorskoe, 2 - Medvezhye, 3 - Olkhovskoe, 4Konstantinovsky, 5 - Torchinskoe, 6 - Karatavskoe) 
Шиндинский интрузив сложен габбро, диоритами, тоналитами, гранодиоритами, плагиогранитами, гранитами. Большинством исследователей становление плутона считается трёхфазным: I габбро, габбро-диориты, диориты; II - кварцевые диориты, гранодиориты, плагиограниты, III - граниты, адамеллиты [25]. На современном эрозионном срезе плутон картируется отдельными массивами - Ольховским, Константиновским, Ничкинским, Подпорожным.

Дайковые образования распространены довольно широко и представлены догранитными (диоритовые порфириты I, лампрофиры I, диабазы I) и послегранитными (аплиты II, диабазы II, лампрофиры II, диоритовые порфириты II) телами. Все они дорудные, а лампрофиры II внутрирудные, поскольку отсекают ранние убого золотоносные пирит-пирротиновые метасоматические залежи от поздних секущих кварц-золото-медносульфидных жил в зонах березитов.

В экзоконтактах гранитоидов с доломитами, осложненными разрывами, залегают магнезиально-известковые скарны с вкрапленными пиритпирротин-халькопиритовыми убого золотоносными рудами и метасоматические золото-медносульфидно-теллуридные залежи. В тектонических трещинах скола и отрыва среди приконтактовых гранитоидов и роговиков распространены кварц-золото-сульфидные жильно-прожилковые руды. Первые два типа руд относятся к скарново-золото-медносульфидной, а третьи - к кварц-золото-сульфидно-березитовой формациям [ $[26,27]$.

\section{Методика исследования}

На золоторудных месторождениях ОльховскоЧибижекского рудного поля (Лысогорском, Медвежьем, Константиновском) было проведено минералого-геохимическое картирование в поверхностных и подземных горных выработках и по керну скважин с отбором образцов и проб-протолочек $(2,5 \ldots 5,0$ кг) для последующих минералогических и геохимических исследований. Было изучено около трехсот монофракций пирита.

Кристалломорфология пирита изучена по образцам, отобранным из рудных тел и околорудных метасоматитов месторождений рудного поля. Изучение кристаллов пирита проводилось на количественной основе по разработанной методике [6], включающей дробление образцов, отбор монофракций пирита и рассеивание их по фракциям от 0,1 до 1,0 мм и более. Систематическое изучение кристаллов пирита разных по размеру фракций одной генерации показало закономерное изменение его морфологии в зависимости от размера изучаемой фракции: с уменьшением изучаемой фракции минерала увеличивается количество типов кристаллов за счёт появления на них слабо развитых граней $\{111\},\{321\},\{211\}[20]$. При этом установлено, что фракция $0,25 \ldots 0,5$ мм наиболее полно характеризует морфологию пирита. Поэтому, во избежание ошибок при сравнении кристаллов пирита разных генераций, ассоциаций и место- рождений, детально изучалась фракция пирита $0,25 \ldots 0,5$ мм, из которой набиралось по $50 \ldots 100$ кристаллов. Остальные фракции изучались менее детально. Кристаллы пирита встречаются как в виде простых форм - гексаэдров $\{100\}$, пентагондодекаэдров $\{210\}$, октаэдров $\{111\}$, так, чаще всего, в виде комбинаций этих простых форм. Кристаллы группировались как в определённые морфологические типы в зависимости от количества простых форм, входящих в комбинацию, и развитости граней, так и в габитусы (кубический, пентагондодекаэдрический, октаэдрический, куб-пентагондодекаэдрический и др.).

Определение элементов-примесей в пиритах проводилось эмиссионно-спектральным полу- и количественным анализами на $\mathrm{Cu}, \mathrm{As}, \mathrm{Sb}, \mathrm{Zn}, \mathrm{Pb}$, $\mathrm{Ag}, \mathrm{Bi}, \mathrm{Co}, \mathrm{Ni}, \mathrm{Mn}, \mathrm{Ti}, \mathrm{Ba}$; предел обнаружения $1 \times 10^{-5} \%$ (Центральная лаборатория Западно-Сибирского геологического управления, г. Новокузнецк и ИРГИРЕДМЕТ, г. Иркутск). Золото определялось инструментальным нейтронно-активационным анализом на ядерном реакторе в НИИ ЯФ Томского политехнического университета, предел обнаружения $-1 \times 10^{-10} \%$ (аналитик В.Л. Чесноков). Содержание урана определялась на флуориметре-абсорциометре «Анализ» с относительной ошибкой измерения $12 \%$; предел обнаружения - $1 \times 10^{-4} \%$ (ИМиГ СО РАН, г. Новосибирск; аналитик З.В. Малясова). Концентрация тория определялась с помощью прибора ФЭК-57 с относительной ошибкой измерения $15 \%$; предел обнаружения - 0,5×10-4 \% (ИМиГ СО РАН, г. Новосибирск; аналитик 3.В. Малясова). Платина и палладий определялись инверсионно вольт-амперометрическим методом в Инновационном научнообразовательном центре «Золото-платина» ТПУ из навески 1 мг с пределами измерений $n \times 10^{-2}-10^{-8} \%$ (аналитики: Э.В. Горчаков - Pd, Э.М. Устинова - Pt).

Определение термо-эдс пиритов проводилось в лаборатории геологии золота Томского политехнического университета на установке, совмещенной с бинокулярным микроскопом МБС- 10 , специально приспособленной для измерения термо-эдс мелких фракций минералов-полупроводников размером $0,2 \ldots 1,0$ мм. Холодный электрод представлен массивной латунной пластиной размером $20 \times 10 \times 0,5$ см (для быстрого его охлаждения), горячий латунный электрод - игловидной формы. Электроды соединены с измерительным цифровым миллиамперметром M-800 F, автоматически показывающим электронный $(-n)$ или дырочный $(+p)$ тип проводимости минерала. Измерение проводилось при постоянной разности температур между холодным и горячим электродами в $150{ }^{\circ} \mathrm{C}$. Калибровка электродов (установление разности температур между холодным и горячим электродами и типа проводимости) осуществлялась с помощью эталонного образца - галенита, который имеет только электронный тип проводимости. Через каждые 10-15 замеров проводились контрольные замеры эталонного галенита. Время одного замера 
термо-эдс минерала составляло $15 . . .20$ с. В каждой пробе производилось 30-50 замеров термо-эдс зерен или кристалликов пирита [28, 29].

\section{Результаты исследования и их обсуждение}

Кристаллолорфология пирита. Кристаллы пирита месторождений Ольховско-Чибижекского рудного поля в рудных телах и околорудных метасоматитах встречаются в виде гексаэдров $\{100\}$, пентагондодекаэдров $\{210\}$, но чаще всего в виде их комбинаций $\{100\}+\{210\}$ или $\{100\}+\{210\}+\{111\}$, где грань октаэдра $\{111\}$ очень слабо развита. Грань тетрагонтриоктаэдра $\{321\}$ в комбинациях кристаллов пирита слабо и неравномерно развита и наиболее часто встречается на кристаллах пирита Лысогорского месторождения (до 50 \%). Редко встречаются хорошо образованные изометрические кристаллы пирита. Чаще всего они искажены, грани их развиты неравномерно. Нередко встречаются псевдоробоэдрические, призматические или игольчатые кристаллы. Грани кристаллов, как правило, покрыты комбинационной штриховкой или, реже, послойной штриховкой роста. Количество морфологических типов кристаллов (МТК) пирита изменяется от 5-10 в ранних минеральных ассоциациях и околорудных метасоматитах, до 15-20 - в продуктивных минеральных ассоциациях и рудных столбах. В некоторых рудных пробах Медвежьего месторождения количество МТК пирита достигает 43.

На Лысогорском месторождении в кварцево-золото-пирит-висмутитовой ассоциации преобладают кристаллы пирита кубического габитуса (до $87 \%$ ), где количество кристаллов в форме кубов достигает $32 \%$. Наибольшая комбинационная устойчивость отмечается у кристаллов $\{100\}+\{321\}$. Другие грани $\{111\},\{210\}$ в комбинациях кристаллов встречаются в 2-3 раза реже по сравнению с гранью $\{100\}$. С глубиной и по простиранию рудных тел, в стороны их выклинивания, сокращается распространенность пиритов кубического габитуса со слабо развитой гранью $\{321\}$ в комбинациях и увеличивается количество кристаллов пирита в комбинациях с гранями $\{210\}$ и $\{111\}$. По данным Г.К. Абдуллаева [30] и Ч.Д. Джафарова [31] грань $\{321\}$ в комбинациях кристаллов пирита встречается чаще всего в низкотемпературных минеральных ассоциациях и верхних частях рудных тел. Это подтверждается и нашими наблюдениями $[18,20]$.

На Медвежьем месторождении пириты продуктивной кварцево-золото-медносульфидной ассоциации представлены в основном кубическим габитусом кристаллов, на долю которого приходится более $60 \%$. И здесь наблюдается наибольшее разнообразие морфологических типов кристаллов, где на габитусных кристаллах появляются слабо развитые грани $\{111\},\{210\},\{321\},\{110\}$. Наибольшая комбинационная устойчивость у кристаллов $\{100\}+\{210\}$ и $\{100\}+\{210\}+\{111\}$. Пириты ранней карбонатно-золото-пирит-пирротиновой ассоциации имеют в основном пентагондодекаэдриче- ский и октаэдрический габитусы, где грань куба $\{100\}$ в комбинациях кристаллов находится в подчинённом положении. И количество морфологических типов кристаллов здесь не превышает 6-10. В околорудных березитах, серицитовых метасоматитах количество МТК сокращается до 4-6, где преобладает кубический габитус кристаллов, на которых слаборазвиты грани $\{111\}$ и $\{210\}$.

В распределении морфологических типов кристаллов пирита проявилась волнообразная вертикальная (с величиной волны $200 \ldots 240$ м) (рис. 2) и горизонтальная зональности: сокращение с глубиной доли кристаллов кубического габитуса (и уменьшение количества МТК) и возрастание доли кубпентагондодекаэдрического (до горизонта 245 м). А в призальбандовых частях золоторудных тел, на контактах с гранодиоритами, возрастает доля кристаллов в комбинации $\{100\}+\{210\}$, а со стороны мраморизованных известняков уменьшается встречаемость грани $\{321\}$ в комбинациях кристаллов. В рудных столбах (горизонты 445...323 и 205...125 м) установлено 2-3-кратное увеличение количества типов кристаллов за счет присутствия на них слаборазвитых граней $\{111\},\{321\},\{211\},\{210\}$. На верхних $(525 \ldots 445 \mathrm{~m})$ и на нижних $(205 . .125$ м) горизонтах месторождения распространены кристаллы пирита кубического габитуса, а в местах выклинивания рудных тел распространены пириты кубпентагондодекаэдрического (рис. 2).

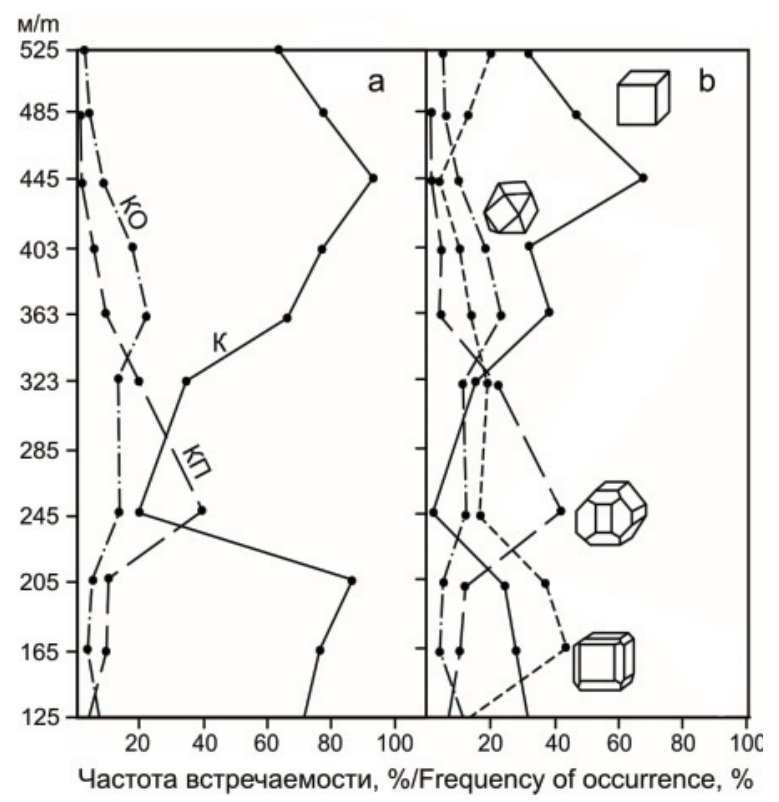

Puc. 2. Изменение частоты встречаемости габитусов (а) и морфологических типов (b) кристаллов пиритов из продуктивной квариево-золото-медносульфидной ассоциации с глубиной месторождения Медвежьего. Габитусы: $\kappa$ - кубический, КП - куб-пентагондодекаэдрический, КО - куб-октаэдрический

Fig. 2. Change in occurrence frequency of habitus (a) and morphological types (b) of pyrite crystals from the productive quartzgold-copper-sulphide association with the depth of the Medvezhye deposit. Habites: $K$ - cubic, $K \Pi$ - cube-pentagonal dodecahedron, $\mathrm{KO}$ - cube-octahedral 
Пириты Константиновского месторождения, расположенного на восточном фланге ОльховскоЧибижекского рудного поля, отличаются от таковых Медвежьего месторождения преобладающим кубическим и куб-пентагондодекаэдрическим габитусами $(60 \ldots 75 \%)$, при полном отсутствии кристаллов в форме октаэдров $\{111\}$ и комбинаций $\{100\}$ с $\{111\}$. При этом грань $\{210\}$ в комбинациях встречается почти у $100 \%$ кристаллов, а грань $\{321\}$ встречается эпизодически (рис. 3). На месторождении отчетливо проявляется зональное размещение морфологических типов кристаллов по простиранию и падению рудных зон. В призальбандовых частях рудных тел количество типов кристаллов пирита меньше, чем в центральных, а в околорудных березитах в 2 раза меньше, чем в рудах. В сторону выклинивания рудных тел уменьшается доля кристаллов кубического габитуса и возрастает куб-пентагондодекаэдрического. С глубиной рудных зон для разнотемпературных минеральных ассоциаций намечается волнообразное (с величиной волны $200 . .240$ м) изменение морфологии кристаллов пирита с наибольшим разнообразием форм в рудных столбах. Количество кристаллов кубического габитуса сокращается (до гор. 357 м), а куб-пентагондодекаэдрического и пентагондодекаэдрического возрастает (рис. 3). Это свидетельствует о более значительном эрозионном срезе Константиновского месторождения по сравнению с Медвежьим.

Изучение кристалломорфологии пиритов протяженной с запада на восток почти на 30 км Ольховско-Чибижекского рудной зоны выявило гори- зонтальную и вертикальную зональность в распределении морфологических типов кристаллов (рис. $2,3)$, которая выражается в смене по падению рудных тел (часто волнообразно с амплитудой $200 \ldots 240$ м) и по простиранию (в стороны их выклинивания) кристаллов пирита кубического на пентагондодекаэдрический габитус. С запада на восток от Лысогорского, Медвежьего до Константиновского месторождений сокращается количество пиритов кубического габитуса, а куб-пентагондодекаэдрического и пентагондодекаэдрического увеличивается (рис. 4). Закономерно увеличивается распространенность морфологических типов кристаллов в комбинациях $\{100\}+\{210\}$, $\{100\}+\{210\}+\{111\}$. Резко сокращается в комбинациях кристаллов частота встречаемости грани $\{321\}$. Все это свидетельствует об увеличении эрозионного среза отдельных структурных блоков этой крупной рудной зоны с запада на восток вдоль её простирания от Лысогорского к Медвежьему и к Константиновскому месторождениям.

Элементы-примеси в пиритах. Проанализированы пириты рудных тел и околорудных метасоматитов месторождений на $\mathrm{Au}, \mathrm{Ag}, \mathrm{Pt}, \mathrm{Pd}, \mathrm{Cu}, \mathrm{Bi}, \mathrm{Pb}$, Zn, Th, Cr, Ni, Co, V, Ti, U, Mo, Hg, As, Sb [18, 22].

Геохимический спектр примесных элементов неодинаков и непостоянен как в пиритах разных месторождений, так и в разнотемпературных минеральных ассоциациях и генерациях одного месторождения. При этом пириты каждого месторождения характеризуется своим комплексом примесных элементов (рис. 6). Так, пириты кварцево-золото-пирит-висмутитовой ассоциации Лы-

\section{Габитусы/Habitatus}

Морфологические типы/Morphological types Частота встречаемости, \%/Frequency of occurrence, \%

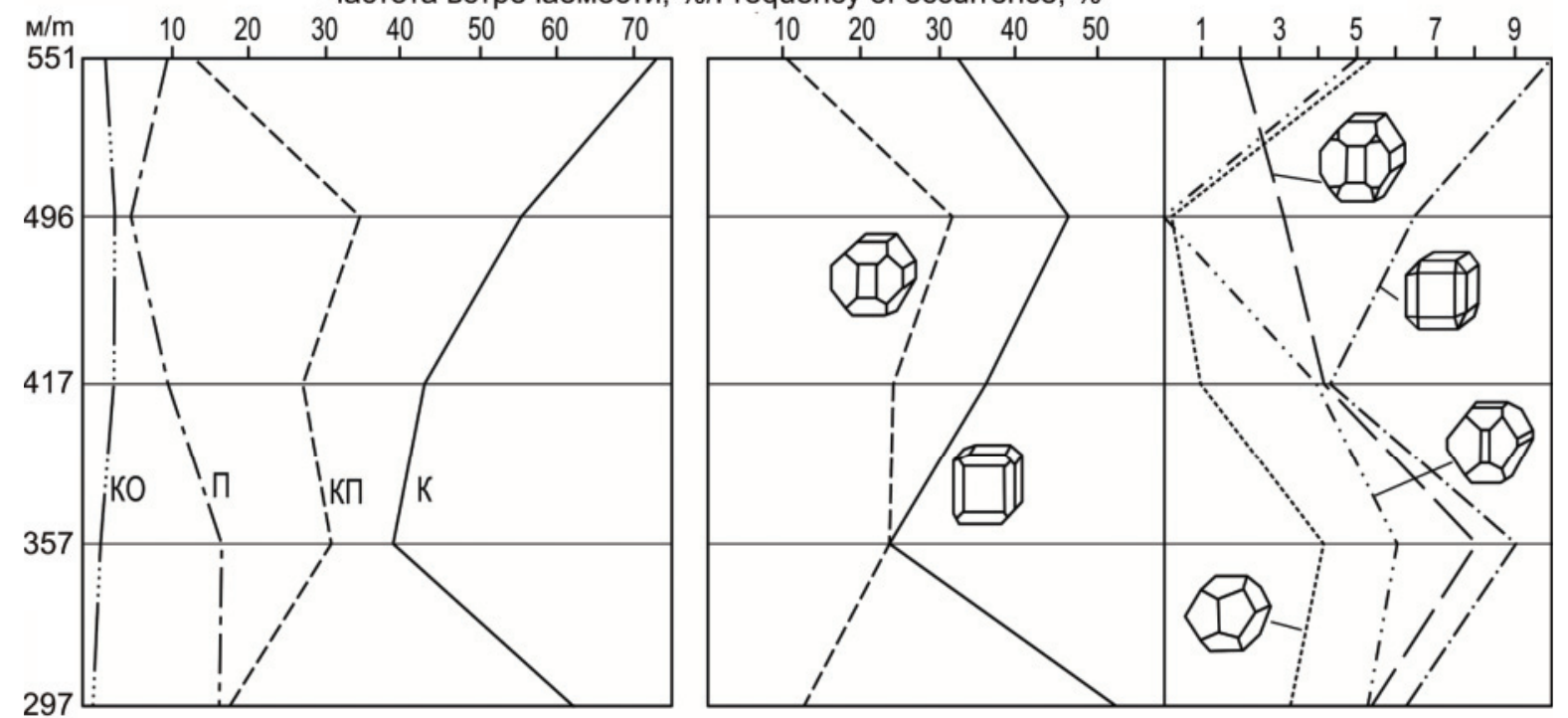

Рис. 3. Изленение встречаелости габитусов и морфологических типов кристаллов пирита из квари-золото-ледносульфидной ассоциации с глубиной месторождения Константиновского. Габитусы: $K$ - кубический, КП - куб-пентагондодекаэдрический, П - пентагондодекаэдрический, КО - куб-октаэдрический

Fig. 3. Change in occurrence of habitus and morphological types of pyrite crystals from quartz-gold-copper-sulphide association with the depth of the Konstantinovsky deposit. Habites: $K$ - cubic, $K \Pi$ - cube-pentagonal dodecahedron, $\Pi$ - pentagonal dodecahedron, KO - cube-octahedral 

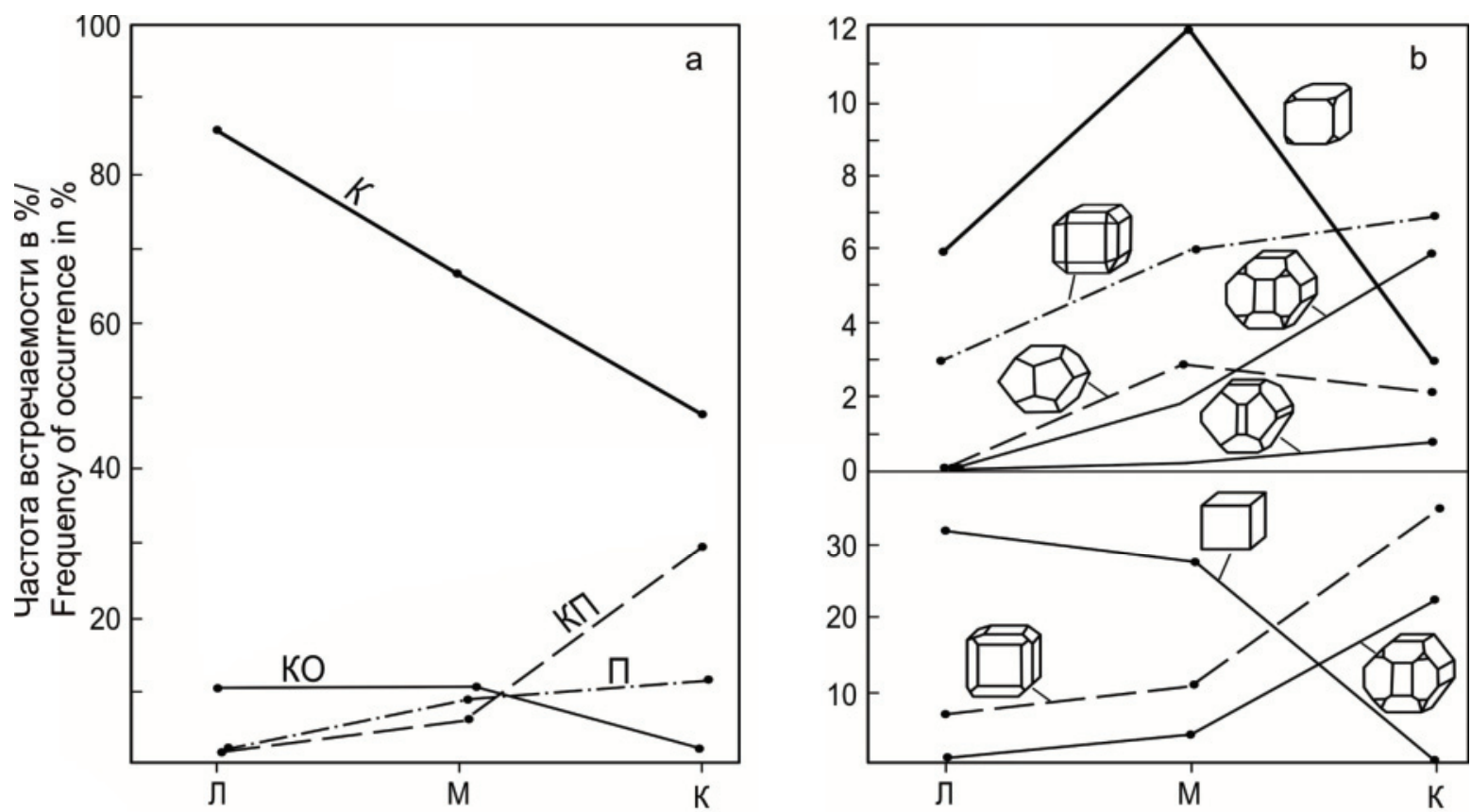

Pис. 4. Изменение встречаемости габитусов (а) и морфологических типов (b) кристаллов пиритов в зависимости от уровня эрозионного среза месторождений Ольховско-Чибижекского рудного поля. Габитусы: $K$ - кубический, КП - куб-пентагондодекаэдриче-

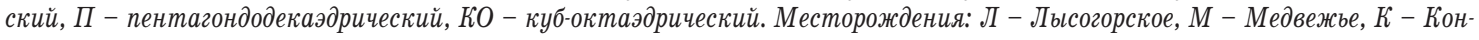
стантиновское

Fig. 4. Change in occurrence of habitus (a) and morphological types (b) of pyrite crystals, depending on the level of erosion cut in the Olkhovsko-Chibizhek ore field. Habites: $K$ - cubic, $K \Pi$-cube-pentagonal dodecahedron, $\Pi$ - pentagonal dodecahedron, $K O$ - cube-octahedral. Deposits: I -Lysogorskoe, $M$ - Medvezhye, $K$ - Konstantinovskoe

согорского месторождения обогащены, по сравнению с другими месторождениями рудного поля, $\mathrm{Hg}, \mathrm{As}, \mathrm{Zn}, \mathrm{Cu}, \mathrm{Bi}, \mathrm{Sb}$ и обеднены Mn, Th, U. Пириты кварцево-золото-медносульфидной продуктивной ассоциации Медвежьего месторождения содержат несколько повышенные концентрации As, $\mathrm{Pb}, \mathrm{Mn}, \mathrm{U}, \mathrm{Cd}$ и обеднены по сравнению с другими месторождениями $\mathrm{Cu}, \mathrm{Co}, \mathrm{Ag}, \mathrm{Bi}$. Для рудных пиритов Константиновского месторождения характерно накопление в повышенных содержаниях As, $\mathrm{Cu}, \mathrm{Pb}, \mathrm{Mn}, \mathrm{Ti}$, и они обеднены или в них отсутствуют $\mathrm{Ba}, \mathrm{Th}, \mathrm{U}, \mathrm{Hg}$.

В пиритах околорудных метасоматитов присутствует тот же комплекс элементов-примесей, что и в пиритах руд, но в значительно более низких концентрациях, также в них не обнаружены или эпизодически встречаются $\mathrm{Ba}, \mathrm{Ag}, \mathrm{Pb}, \mathrm{Mo}, \mathrm{Sb}$.

В распределении примесных элементов в пиритах месторождений наблюдается вертикальная и горизонтальная зональность. Пириты из прикорневых частей рудных тел обычно обогащены в $1,5 . .5$ раз и более $\mathrm{Ni}, \mathrm{Co}, \mathrm{Cu}, \mathrm{Mn}$, нередко As. А пириты верхних горизонтов рудных тел и надрудных ореолов - Ba, $\mathrm{Hg}, \mathrm{Ag}$, Sb. Максимально обогащены примесными элементами, в том числе золотом, пириты из рудных столбов. В местах выклинивания рудных тел как по простиранию, так и падению количество примесных элементов уменьшается до минимума. По падению рудных тел Медвежьего (рис. 5) и Константиновского месторождений концентрация элементов в пиритах изменяется часто волнообразно с амплитудой волны $200 \ldots 240$ м в соответствии со структурно-минералогической 30нальностью месторождений. Максимум волны совпадает с наиболее обогащенными рудой горизонтами, а минимумы - с местами их выклинивания.

Золото обнаружено во всех проанализированных пиритах рудных тел и околорудных метасоматитах месторождений рудного поля в количестве $0,1 \ldots 200$ г/т, при средних значениях в разных рудных телах $3 . . .47$ г/т. Наибольшая его концентрация выявлена в рудогенных пиритах кварцево-золото-медносульфидной ассоциации Константиновского $(47,7$ г/т) и Медвежьего $(27,6$ г/т) месторождений, а в пиритах ранней карбонатно-золото-пирит-пирротиновой ассоциации месторождений почти в $3-5$ раз меньше $(10,5$ г/т). В пиритах кварцево-золото-пирит-висмутитовых жилах Лысогорского месторождения установлены самые низкие содержания золота от 0,1 до 9 г/т, при среднем значении 3,6 г/т. В пиритах околорудных метасоматитов содержание золота невысокое - 3,6...4,9 г/т, при разбросе концентраций от 0,1 до 10,0 г/т.

С глубиной рудных зон и рудных тел установлено волнообразное (с амплитудой в $200 \ldots 240$ м) распределение золота с максимальными концентрациями его в пиритах рудных столбов. При этом минимальные содержания Au характерны для пиритов участков выклинивания рудных тел. Для Медвежьего (рис. 5) и Константиновского месторождений выявлено возрастание содержаний $\mathrm{Au}$ в пиритах нижних эксплуатационных горизонтов. 


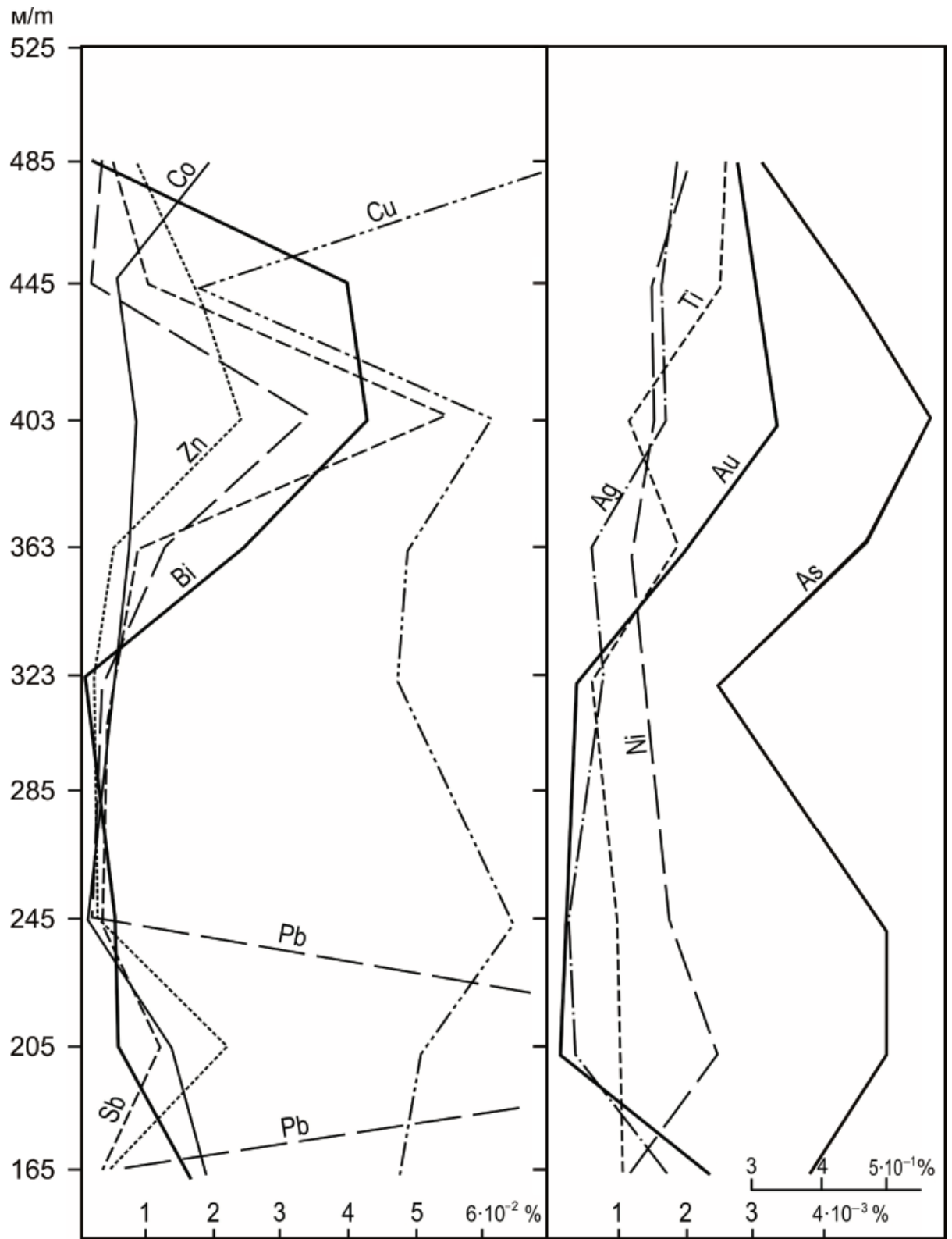

Pис. 5. Изленение средних содержаний элементов-примесей в пиритах с глубиной квариево-золото-медносульфидной ассоциации Медвежьего месторождения

Fig. 5. Change in average content of impurity elements in pyrite with the depth of the quartz-gold-copper sulphide association of the Medvezhye deposit

Впервые проведенные инверсионно-вольтамперометрические определения платины и палладия в ряде проб пирита из руд и околорудных метасоматитов месторождений рудного поля показали, что платина содержится почти во всех проанализированных пробах с крайне неравномерным её распределением от 0,05 до 34,0 г/т. Наиболее обогащены платиной пириты продуктивной кварц-золото-медносульфидной ассоциации Медвежьего $(0,05 \ldots 15,2$ г/т), Константиновского $(0,05 \ldots 30,2$ г/т) и кварцево-золото-пирит-висмут итовой ассо ци аци Лысогорского $(0,05 \ldots 34,0$ г/т) месторождений. В пиритах околорудных метасоматитов содержание платины на порядок ниже, чем в пиритах руд. Концентрации палладия в пиритах руд месторождений значительно ниже $(0,02 \ldots 1,9$ г/т), чем в пиритах руд [22].

Проведённое нами изучение хвостов обогащения (эфелей) Ольховской обогатительной фабрики показало, что в них содержатся повышенные содержания платины и палладия - в среднем 1,5 и 0,2 г/т соответственно.

Намечается определённая зональность в распределении элементов-примесей в пиритах рудных тел и околорудных метасоматитов с запада на восток от Лысогорского месторождения к Медвежьему и Константиновскому (рис. 6). Так, в этом 

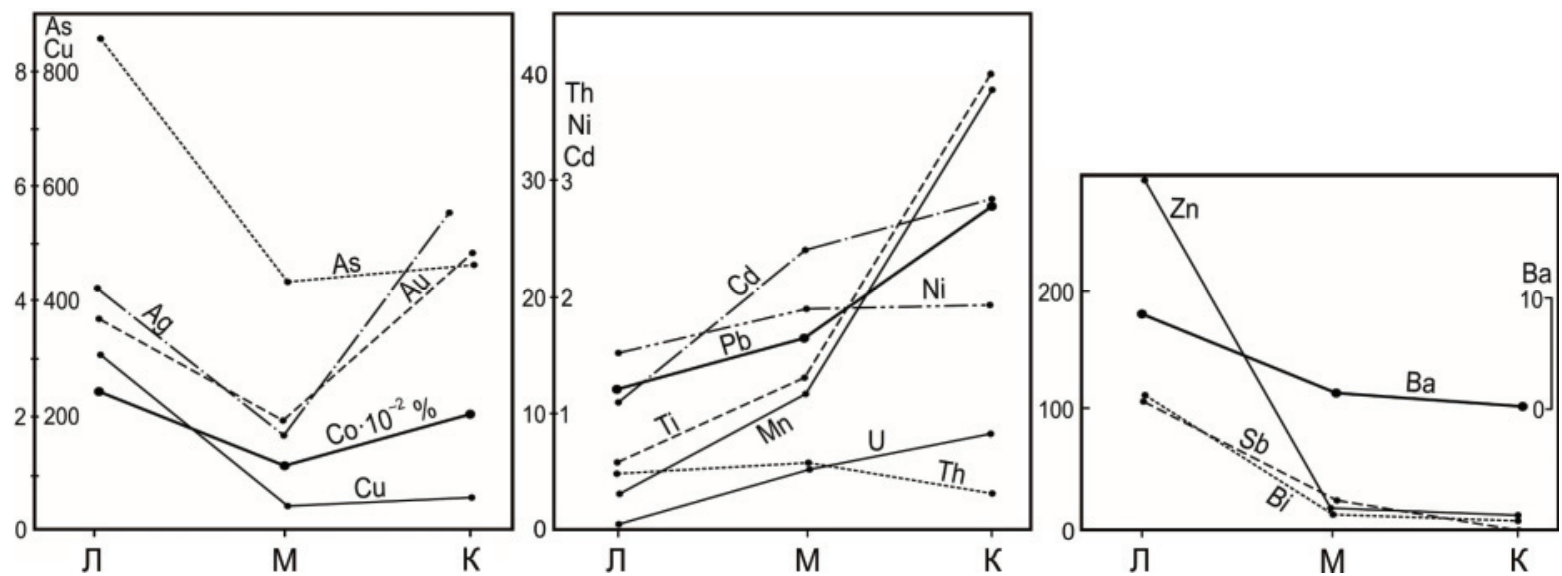

Pис. 6. Изленение средних содержаний ( $n \cdot 10^{-3 \%}$ ) элементов-примесей в пиритах в зависилости от уровня эрозионного среза лесторождений Ольховско-Чибижекского рудного поля

Fig. 6. Change in average contents $\left(n \cdot 10^{-3} \%\right)$ of impurity elements in pyrite, depending on the level of erosion cut of the Olkhovsko-Chibizhek ore deposit

направлении в пиритах увеличивается содержание $\mathrm{Ti}, \mathrm{Mn}, \mathrm{Pb}, \mathrm{U}, \mathrm{Cd}$, частично - Со и $\mathrm{Ni}$, и уменьшается - Hg, Ba, Sb, Zn, Bi, U. Это подчёркивает увеличение уровня эрозионного среза месторождений от Лысогорского к Медвежьему и Константиновскому месторождениям.

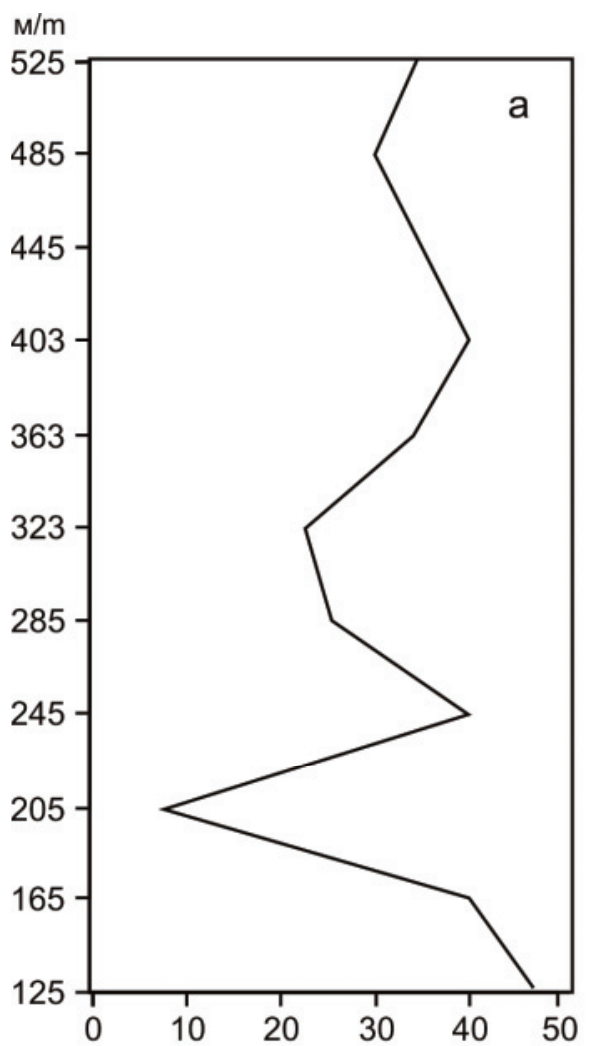

Таким образом, зональное распределение элементов-примесей в пиритах руд и околорудных метасоматитов позволяет использовать состав пирита для относительной оценки уровня эрозионного среза рудных тел и давать их прогнозную оценку на глубину и фланги.

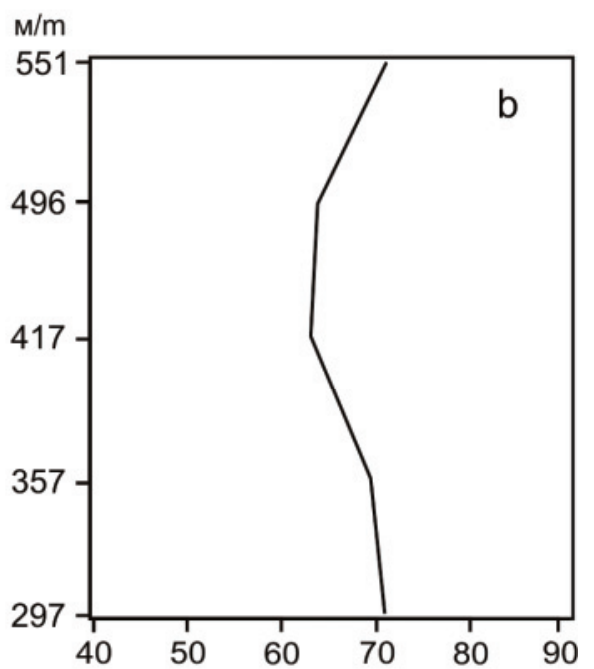

Доля электронной проводимости ТЭДС в \%/ The fraction of the electronic conductivity of the termo-emf in \%

Puс. 7. Изменение долей электронной проводимости термо-эдс пиритов с глубиной Медвежьего (a) и Константиновского (b) месторождений

Fig. 7. Change in fraction of electron conductivity of thermo-emf of pyrites with the depth of Medvezhye (a) and Konstantinovskoe (b) deposits 
Терлоэлектрические свойства пирита. Термо-эдс пиритов золоторудных (и других типов) месторождений является экспрессным и информативным типоморфным признаком, который закономерно изменяется в пространстве и во времени: от пиритов с электронной проводимостью $(n)$ и ранних высокотемпературных минеральных ассоциаций и прикорневых частей рудных тел к пиритам со смешенным типом проводимости $(n-p)$ и средних частей рудных тел и к пиритам с дырочной $(p)$ проводимостью заключительных минеральных ассоциаций формирования месторождений и верхних частей рудных тел. Основными причинами изменчивости термо-эдс пирита является отклонение от стехиометрии его основных компонентов (Fе и $\mathrm{S}$ ) или изоморфное вхождение в структуру минерала (с замещением Fe или S) 3-валентных $\mathrm{Ni}, \mathrm{Co}, \mathrm{As}$, Ti и др., которые влияют на электронный тип проводимости. Двух- (Pb, Zn, Bi и др.) и одновалентные ( $\mathrm{Sb}, \mathrm{Hg}, \mathrm{Ag}, \mathrm{Au}$ ) элементы, даже если они входят изоморфно в структуру минерала, на знак проводимости не влияют. Они могут или увеличивать значения эдс пирита, или уменьшать [28, 32].

Пириты рудных тел и околорудных метасоматитов Медвежьего и Константиновского месторождений Ольховско-Чибижекского рудного поля характеризуются незначительным разбросом положительных $(p)(+22 \ldots+29 \mathrm{mB})$ и отрицательных $(n)$ $(-17 \ldots-20$ мВ) значений термо-эдс. Но на Медвежьем месторождении в золотых рудах преобладают пириты с дырочной $(p)$ проводимостью $(55 . .67 \%$ ), а на Константиновском, напротив, господствуют пириты с электронной $(n)$ проводимостью (64...82 \% ). Пириты Лысогорского месторождения характеризуются преобладающей дырочной (p) проводимостью $(61 . .68 \%$ ), что свидетельствует в пользу средне-низкотемпературных условий формирования месторождения.

С глубиной отдельных рудных зон и рудных тел Медвежьего и Константиновского месторождений значения термо-эдс пирита, как с электронной, так и дырочной проводимостью, изменяются волнообразно (как кристалломорфологии и элементов-примесей пирита) с максимумами в рудных столбах при общей тенденции увеличения с глубиной доли пирита с электронной проводимостью (рис. 7). По простиранию Ольховско-Чибижекского рудного поля с запада на восток от Лысогорского к Медвежьему и Константиновскому месторождениям намечается закономерное увеличение доли электронной проводимости пиритов как из рудных тел месторождений, так и из околорудных метасоматитов (рис. 8).

Таким образом, для рудных объектов Ольховско-Чибижекского рудного поля отмечается зональное размещение пиритов с изменчивыми показателями термо-эдс по падению и простиранию рудно-метасоматических зон, которые отражают различные уровни эрозионного среза отдельных месторождений.

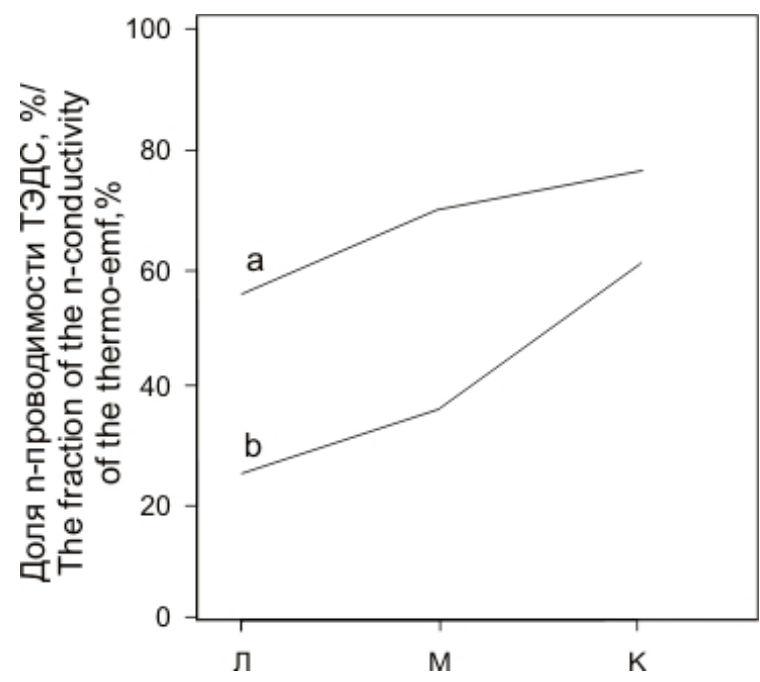

Рис.8. Изменение доли электронной проводимости пиритов в зависилости от уровня эрозионного среза месторождений Ольхово-Чибежекского рудного поля: а) термо-эдс пиритов околорудных метасоматитов; b) терло-эдс пиритов руд

Fig. 8. Change in the share of electronic conductivity of pyrites, depending on the level of erosion cuts in the Olkhovo-Chibezhsky ore field: a) thermo-emf of pyrites around ore metasomatites; b) thermo-emf of pyrites of ores

\section{Выводы}

1. Пирит является наиболее распространённым и информативным сульфидным минералом разнотемпературных минеральных ассоциаций золоторудных месторождений Ольховско-Чибижекского рудного поля.

2. Типоморфные свойства пирита - кристалломорфология, элементы-примеси, термо-эдс закономерно изменяются в объёме рудных тел месторождений волнообразно (с глубиной с амплитудой волны $200 \ldots 240$ м) и от ранних высокотемпературных минеральных ассоциаций к заключительным этапам формирования месторождений.

3. Пириты рудного поля представлены в основном кристаллами кубического габитуса, количество кристаллов которого закономерно уменьшается с запада на восток (и волнообразно с глубиной месторождений) от Лысогорского к Медвежьему и Константиновскому месторождениям, а незначительное количество кристаллов кубпентагондодекаэдрического и пентагондодекаэдрического габитусов несколько увеличивается в этом же направлении. Наибольшая комбинационная устойчивость кристаллов пирита у $\{100\}+\{210\},\{100\}+\{210\}+\{111\}$, а на Лысогорском месторождении - $\{100\}+\{321\}$ (более $50 \%$ ), где грань $\{321\}$ в комбинациях кристаллов слабо развита и характерна в основном для низкотемпературных минеральных ассоциаций и верхних частей рудных тел.

4. Пириты рудных тел месторождений несут определенный комплекс элементов-примесей $\mathrm{Ag}$, 
$\mathrm{Pb}, \mathrm{Zn}, \mathrm{Pt}, \mathrm{As}$ и особенно Au, весьма характерных для многих золоторудных объектов Сибири и других регионов. При этом верхние части рудных зон и надрудные ореолы обогащены пиритами с повышенными содержаниями $\mathrm{Ag}, \mathrm{Ba}$, $\mathrm{Sb}, \mathrm{Hg}$, пириты средних частей рудных тел и рудных столбов резко обогащены $\mathrm{Au}, \mathrm{Ag}, \mathrm{Cu}$, $\mathrm{Pb}, \mathrm{Zn}, \mathrm{Bi}, \mathrm{Pt}$, а в прикорневых участках и в местах их выклинивания по простиранию и падению в пиритах накапливаются Ni, Co, U, нередко As.

5. Впервые в пиритах месторождений ОльховскоЧибижекского рудного поля и эфелях Ольховской обогатительной фабрики выявлены повышенные концентрации платины и палладия.

6. Пириты рудных тел и околорудных метасоматитов месторождений рудного поля характеризуются своими параметрами термо-эдс, обусловленными их генезисом, и имеют преобладающую электронную (Константиновское), электронно-дырочную (Медвежье) или дырочную (Лысогорское) проводимость и незначительный разброс положительных $(p)(+22 \ldots+29 \mathrm{mB})$ и отрицательных $(n)(-17 \ldots-20 \mathrm{mB})$ значений термоэдс. С глубиной рудных тел волнообразно увели-

\section{СПИСОК ЛИТЕРАТУРЫ}

1. Юшкин Н.П. Топоминералогия. - М.: Недра, 1982. - 288 с.

2. Литошко Д.Н. Топоминералогия медно-молибденовой рудной формации Полярного Урала. - Л.: Наука, 1988. - 212 с.

3. Savage K.S., Stefan D., Lehner S.W. Impurities and heterogeneity in pyrite: Influences on electrical properties and oxidation products // Applied Geochemistry. - 2008. - V. 23. - № 2. P. $103-120$.

4. Trace-element characteristics of different pyrite types in Mesoarchaean to Palaeoproterozoic placer deposits / N. Koglin, H.E. Frimmel, W.E.L. Minter, H. Brätz // Mineralium Deposita. - 2010. - V. 45. - № 3. - P. 259-280.

5. The Pampe gold deposit (Ghana): Constraints on sulfide evolution during gold mineralization / S. Salvi, G. Velásquez, J.M. Miller, D. Béziat, L. Siebenaller, Y. Bourassa // Ore Geology Reviews. 2016. - V. 78. - P. 673-686.

6. Пшеничкин А.Я. Использование кристалломорфологии пирита при минералогическом картировании золоторудных месторождений Алтае-Саянской складчатой области // Минералогическое картирование рудоносных территорий. - Свердловск: УНЦ АН СССР, 1985. - C. 60-71.

7. Gold in Pyrite within Altai-Sayan Folded Belt Gold Deposits / A.Y. Pshenichkin, Y.A. Oskina, O.V. Savinova, T.F. Dolgaya // IOP Conference Series: Earth and Environmental Science. 2014. - V. 21. - P. 1-4. DOI: 10.1088/1755-1315/21/1/012005.

8. Reflectivity and microhardness of sulfide minerals as genetic information source (case study: Pyrite and arsenopyrite) / E.A. Sinkina, M.V. Korovkin, O.V. Savinova, A.A. Makarova // IOP Conference Series: Earth and Environmental Science. - 2016. - V. 33. DOI: $10.1088 / 1755-1315 / 33 / 1 / 012053$.

9. Ore mineralogy of the Osikonmaki gold deposits, Rantasalmi, Southeastern Finland / O. Kontoniemi, B. Johanson, K. Kojonen, L. Pakkanen // Geological Survey of Finland. - 1991. - V. 12. P. 81-89.

10. Wall Rock Alterations and Physicochemical Conditions of the Sovetsk Gold Deposit Formation (Enisei Ridge) / O.V. Rusinova, чивается доля электронного типа проводимости пиритов. С запада на восток рудного поля от Лысогорского к Медвежьему и Константиновскому месторождениям закономерно увеличивается электронный тип проводимости пиритов как из продуктивных минеральных ассоциаций, так и из околорудных метасоматитов, что подчёркивает увеличение в этом направлении уровня эрозионного среза месторождений.

7. На основании выявленных типоморфных признаков пиритов: кристалломорфологии, элементов-примесей и термо-эдс, закономерно изменяющихся в пространстве и во времени, можно судить об уровне эрозионного среза рудных тел и месторождений, их перспективности на глубину и фланги. Так, Лысогорское месторождение перспективно на глубину и фланги (верхний уровень эрозионного среза месторождений рудного поля), Медвежье и Константиновское месторождения перспективны на глубокие горизонты.

8. Минералогическое картирование по пириту на золото необходимо проводить (в комплексе с другими методами исследования) на всех стадиях геологоразведочных работ.

V.L. Rusinov, S.S. Abramov, S.V. Kuznetsova, Yu.V. Vasyuta // Geology of Ore Deposits. - 1999. - V. 41 (4). - P. 276-294.

11. Paragenesis and composition of ore minerals in the Randalls BIFhosted gold deposits, Yilgarn Craton, Western Australia: Implications for the timing of deposit formation and constraints on gold sources / J.A. Steadman, R.R. Large, G.J. Davidson, S.W. Bull, J. Thompson, T.R. Ireland, P. Holden // Precambrian Research. - 2014. - V. 243. - P. 110-132.

12. Anomaly Geochemical Fields in Siberian Hydrothermal Gold Deposits / V.G. Voroshilov, O.V. Savinova, Y.S. Ananjev, R.N. Abramova // IOP Conference Series: Earth and Environmental Science. 2014. - V. 21. - P. 1-6. DOI: 10.1088/1755-1315/21/1/012009.

13. Mineralogical, chemical and micromorphological studies of the argillic alteration zone of the epithermal gold deposit Ovacik, Western Turkey: tools for applied and genetic economic geology / H.G. Dill, R. Dohrmann, S. Kaufhold, G. Cicek // Journal of Geochemical Exploration. - 2014. - V. 148. - P. 105-127.

14. Estimating Gold-ore Mineralization Potential Within Topolninsk Ore Field (Gorny Altai) / T. Timkin, V. Voroshilov, 0. Askanakova, T. Cherkasova, A. Chernyshov, T. Korotchenk // Earth and Environmental Science: IOP Conference Series. - 2015. - V. 43. DOI: $10.1088 / 1755-1315 / 27 / 1 / 012010$.

15. Sinkina E.A., Savinova 0.V., Nepryakhina 0.B. Geology, mineralogy and fluid inclusion studies of the Chertovo Koryto deposit, North Transbaikal, Russia // Science and Technologies in Geology, Exploration and Mining: $16^{\text {th }}$ International Multidisciplinary Scientific GeoConference, SGEM 2016. - Albena, Bulgaria, 30 June 2016 - 6 July 2016. Code 124231. DOI: 10.5593/SGEM2016/B11/S01.028.

16. Peculiarities of pyrrhotite mineralization in the Chertovo Koryto deposit (Patom Uplands) / E.A. Sinkina, O.V. Savinova, 0.B. Nepryakhina, Yu.V. Kolbysheva // IOP Conference Series: Earth and Environmental Science. - 2016 - V. 43. DOI: $10.1088 / 1755-1315 / 43 / 1 / 012011$.

17. Formation of epizonal gold mineralization within the Latimojong Metamorphic Complex, Sulawesi, Indonesia: Evidence from mine- 
ralogy, fluid inclusions and Raman spectroscopy / A.Y.A. Hakim, F. Melcher, W. Prochaska, R. Bakker, G. Rantitsch // Ore Geology Reviews. - 2018. - V. 97. - P. 88-108.

18. Коробейников А.Ф., Пшеничкин А.Я. Геохимические особенности пирита золоторудных месторождений // Геохимия. 1985. - № 1. - C. 93-104.

19. Пириты золоторудных месторождений (свойства, зональность, практическое применение) / А.Ф. Коробейников, В.А. Нарсеев, А.Я. Пшеничкин, П.С. Ревякин, Ч.Х. Арифулов. - М.: ЦНИГРИ, 1993. - 216 с.

20. Пшеничкин А.Я. Кристалломорфология пирита и её использование в практике поисково-разведочных работ на золото // Геология и геофизика. - 1989. - № 11. - С. 65-75.

21. Булынников А.Я. Золоторудные формации и золотоносные провинции Алтае-Саянской горной системы // Труды Томского государственного университета. - 1948. - Т. 102. - С. 299.

22. Рудно-метасоматическая и геохимическая зональность золоторудных полей и месторождений складчатых поясов Сибири / А.Ф. Коробейников, Ю.С. Ананьев, А.И. Гусев, В.Г. Ворошилов, Г.Г. Номоконова, А.Я. Пшеничкин, Т.В. Тимкин / отв. ред. А.Ф. Коробейников - Томск: Изд-во ТПУ, 2013. - 458 с.

23. Ворошилов В.Г., Ананьев Ю.С. Рудно-метасоматическая и геохимическая зональность Каратавского рудопроявления золота (Восточный Саян) // Известия Томского политехнического университета. - 2003. - Т. 306. - № 4. - С. 33-38.

24. Кузнецов Ю.А. Главные типы магматических формаций. - М.: Недра, 1964. - 387 с.

25. Беззубцев В.В., Дятлова И.Н. Некоторые проблемы стратиграфии верхнего рифея-кембрия центральной части Саяно-Алтайской складчатой области (в свете усовершенствования се- рийных легенд ГДП-200/2) // URL: http://www.geologica.su/ $? \mathrm{p}=80 \#$ more-80 (дата обращения: 10.10 .2018 ).

26. Шиндинский плутон Ольховского гранитоидного комплекса (Восточный Саян) / Г.В. Поляков, Г.С. Федосеев, А.Е. Телешев, С.М. Николаев // Магматические формации Алтае-Саянской складчатой области. - М.: Наука, 1965. - С. 84-111.

27. Коробейников А.Ф. Нетрадиционные комплексные золотоплатиноидные месторождения складчатых поясов. - Новосибирск: СО РАН НИЦ ОИГГМ, 1999. - 237 с.

28. Пшеничкин А.Я. Термоэлектрические свойства пиритов некоторых золоторудных месторождений различных типов // Известия Томского политехнического института. - 1977. T. 247. - C. 74-78.

29. Пшеничкин А.Я., Гаврилов Р.Ю. Пириты западного фланга Сухоложского золоторудного поля (Ленский рудный район) // Известия Томского политехнического университета. Инжиниринг георесурсов. - 2018. - Т. 329. - № 5. - С. 135-143.

30. Абдуллаев Г.К. К вопросу о морфологии кристаллов пирита с условиями их образования. - Доклады АН АзербССР. 1957. - Т. 13. - № 1. - С. 43-48.

31. Джафаров Ч.Д. Кристалломорфология пирита и её минералогическое значение. - Баку: Элм, 1970. - 118 с.

32. Пшеничкин А.Я., Коробейников А.Ф., Мацюшевский А.В. Особенности кристалломорфологии и термо-эдс пиритов золоторудных месторождений различных типов // Известия Томского политехнического института. - 1976. - Т. 260. C. $39-48$.

Поступила 30.10.2018 2.

\section{Информация об авторах}

Пшеничкин A.Я., кандидат геолого-минералогических наук, заведующий лабораторией геологии золота отделения геологии Инженерной школы природных ресурсов Национального исследовательского Томского политехнического университета.

Гаврилов Р.Ю., кандидат геолого-минералогических наук, доцент отделения геологии Инженерной школы природных ресурсов Национального исследовательского Томского политехнического университета. 
UDK 553.411:549.324.31

\title{
TYPOMORPHISM OF PYRITES OF THE OLHOVSK-CHIBIZHEK GOLD FIELD (EAST SAYAN)
}

\section{Anatoliy Ya. Pshenichkin',}

paya@tpu.ru

\author{
Roman Yu. Gavrilov', \\ GavrilovRY@tpu.ru \\ ${ }^{1}$ National Research Tomsk Polytechnic University,
30, Lenin Avenue, Tomsk, 634050, Russia.
}

The relevance of the work is caused by the need for a comprehensive mineralogical-geochemical study of gold deposits to create predictive-search models of ore objects.

The aim of the research is to study the typomorphic properties of pyrite (crystallomorphology, element-impurities, thermo-emf) from different-temperature mineral associations and generations of ore bodies and near-ore metasomatites of gold ore deposits in the Olkhovsko-Chibizhek ore field.

Methods: crystallomorphology, thermo-emf, statistical processing of geochemical data, spatial modeling of typomorphic properties of pyrite.

Results. Typomorphic properties of pyrite-crystal - morphology, impurity elements, thermo-emf, naturally vary in the volume of ore bodies in the Olkhovsko-Chibizhek ore field deposits and from early high-temperature mineral associations to the final stages of formation of deposits. Pyrites of deposits of the ore field are mainly represented by crystals of cubic habit, the number of crystals of which regularly decreases from west to east (and wave-like with the depth of ore bodies with wave amplitude $200 . .240 \mathrm{~m}$ ) from Lysogorskoe to Medvezhye and Konstantinovskoe deposits. The greatest combination resistance of pyrite crystals in $\{100\}+\{210\},\{100\}+\{210\}+\{111\}$, and at Lysogorskoe deposit - $\{100\}+\{321\}$ (more than $50 \%$ ), where the $\{321\}$ face crystals is poorly developed and is characteristic of lowtemperature mineral associations and upper parts of ore bodies. Pyrites of ore bodies of deposits are enriched with Ag, Pb, Zn, Pt, As and especially $\mathrm{Au}$, which are very characteristic for many gold ore objects in Siberia and other regions. In the pyrites of the upper parts of ore zones and overhead haloes, the concentrations of $\mathrm{Ag}, \mathrm{Ba}, \mathrm{Sb}$, and $\mathrm{Hg}$ are high, and the pyrites of the middle parts of ore bodies and ore columns are greatly enriched in $\mathrm{Au}, \mathrm{Ag}, \mathrm{Cu}, \mathrm{Pb}, \mathrm{Zn}, \mathrm{Bi}, \mathrm{Pt}$, in the basal areas and in places of their wedging along the strike and dip in pyrite, Ni, Co, U, often As. Increased concentrations of Pt and Pd were detected in the pyrite deposits of the ore field and in the ephes of the Olkhov concentrator. Pyrites of ore bodies and ore metasomatites of ore field deposits have predominant electronic (Konstantinovskoe), electron-hole (Medvezhye) or hole (Lysogorskoe) conductivity. With the depth of ore bodies and from the west to the east of the ore field from Lysogorskoe to Medvezhye and Konstantinovskoe deposits, the electronic type of conductivity of pyrites naturally increases, both from productive mineral associations and from near-ore metasomatites. Based on the revealed typomorphic features of pyrite: crystallomorphology, element-impurities and thermo-emf, regularly changing in space and time, one can judge the level of erosion cut of ore bodies and deposits, their prospects to depth and flanks. Mineralogical mapping of pyrite to gold must be carried out (in conjunction with other methods of investigation) at all stages of geological exploration.

Key words:

Gold mineralization, pyrite, crystal morphology, thermal electromotive force, impurity elements.

\section{REFERENCES}

1. Yushkin N.P. Topomineralogiya [Topomineralogy]. Moscow, Nedra Publ., 1982. 288 p.

2. Litoshko D.N. Topomineralogiya medno-molibdenovoy rudnoy formatsii Polyarnogo Urala [Topomineralogy of a copper-molybdenum ore formation of Polar Ural Mountains]. Leningrad, Nauka Publ., 1988. 212 p.

3. Savage K.S., Stefan D., Lehner S.W. Impurities and heterogeneity in pyrite: Influences on electrical properties and oxidation products. Applied Geochemistry, 2008, vol. 23, no. 2, pp. 103-120.

4. Koglin N., Frimmel H.E., Minter W.E.L., Brätz H. Trace-element characteristics of different pyrite types in Mesoarchaean to Palaeoproterozoic placer deposits. Mineralium Deposita, 2010, vol. 45 , no. 3, pp. 259-280.

5. Salvi S., Velásquez G., Miller J.M., Béziat D., Siebenaller L., Bourassa Y. The Pampe gold deposit (Ghana): Constraints on sulfide evolution during gold mineralization. Ore Geology Reviews, 2016, vol. 78, pp. 673-686.

6. Pshenichkin A.Ya. Ispolzovanie kristallomorfologii pirita pri mineralogicheskom kartirovanii zolotorudnykh mestorozhdeniy Altae-Sayanskoy skladchatoy oblasti [Use of crystal morphology of pyrite in mineralogical mapping of gold deposits of the Altai-Sayan folded region]. Mineralogicheskoe kartirovanie rudonosnykh territory [Mineralogical mapping of ore-bearing territories].
Sverdlovsk, UNSC of the USSR Academy of Sciences Publ., 1985. pp. 60-71.

7. Pshenichkin A., Oskina Y., Savinova 0., Dolgaya T. Gold in Pyrite within Altai-Sayan Folded Belt Gold Deposits. IOP Conference Series: Earth and Environmental Science. Tomsk; Russian Federation; 7-11 April 2014, vol. 21. DOI: 10.1088/1755-1315/21/1/012005.

8. Sinkina E.A., Korovkin M.V., Savinova 0.V., Makarova A.A. Reflectivity and microhardness of sulfide minerals as genetic information source (case study: Pyrite and arsenopyrite). IOP Conference Series: Earth and Environmental Science, 2016, vol. 33. DOI: $10.1088 / 1755-1315 / 33 / 1 / 012053$.

9. Kontoniemi O., Johanson B., Kojonen K., Pakkanen L. Ore mineralogy of the Osikonmaki gold deposits, Rantasalmi, Southeastern Finland. Geological Survey of Finland, 1991, vol. 12, pp. 81-89.

10. Rusinova O.V., Rusinov V.L., Abramov S.S., Kuznetsova S.V., Vasyuta Yu.V. Wall Rock Alterations and Physicochemical Conditions of the Sovetsk Gold Deposit Formation (Enisei Ridge). Geology of Ore Deposits, 1999, vol. 41 (4), pp. 276-294.

11. Steadman J.A., Large R.R., Davidson G.J., Bull S.W., Thompson J., Ireland T.R., Holden P. Paragenesis and composition of ore minerals in the Randalls BIF-hosted gold deposits, Yilgarn Craton, Western Australia: Implications for the timing of deposit formation and constraints on gold sources. Precambrian Research, 2014, vol. 243, pp. 110-132. 
12. Voroshilov V.G., Savinova O.V., Ananjev Y.S., Abramova R.N Anomaly Geochemical Fields in Siberian Hydrothermal Gold Deposits. IOP Conference Series: Earth and Environmental Science, 2014, vol. 21, pp. 1-6. D0I: 10.1088/1755-1315/21/1/012009.

13. Dill H.G., Dohrmann R., Kaufhold S., Cicek G. Mineralogical, chemical and micromorphological studies of the argillic alteration zone of the epithermal gold deposit Ovacik, Western Turkey: tools for applied and genetic economic geology. Journal of Geochemical Exploration, 2014, vol. 148, pp. 105-127.

14. Timkin T., Voroshilov V., Askanakova 0., Cherkasova T., Chernyshov A., Korotchenk T. Estimating Gold-ore Mineralization Potential Within Topolninsk Ore Field (Gorny Altai). IOP Conference Series: Earth and Environmental Science, 2015, vol. 43. DOI: $10.1088 / 1755-1315 / 27 / 1 / 012010$.

15. Sinkina E.A., Savinova 0.V., Nepryakhina 0.B. Geology, mineralogy and fluid inclusion studies of the Chertovo Koryto deposit, North Transbaikal, Russia. Science and Technologies in Geology, Exploration and Mining: $16^{\text {th }}$ International Multidisciplinary Scientific GeoConference, SGEM 2016. Albena, Bulgaria, 30 June 2016 - 6 July 2016; Code 124231. DOI: 10.5593/SGEM2016/B11/S01.028.

16. Sinkina E.A., Savinova O.V., Nepryakhina 0.B., Kolbysheva Yu.V. Peculiarities of pyrrhotite mineralization in the Chertovo Koryto deposit (Patom Uplands). IOP Conference Series: Earth and Environmental Science, 2016, vol. 43. DOI: 10.1088/1755-1315/43/1/012011.

17. Hakim A.Y.A., Melcher F., Prochaska W., Bakker R., Rantitsch G. Formation of epizonal gold mineralization within the Latimojong Metamorphic Complex, Sulawesi, Indonesia: Evidence from mineralogy, fluid inclusions and Raman spectroscopy. Ore Geology Reviews, 2018, vol. 97, pp. 88-108.

18. Korobeynikov A.F., Pshenichkin A.Ya. Geokhimicheskie osobennosti pirita zolotorudnykh mestorozhdeniy [Geochemical features of pyrite of gold deposits]. Geochemistry, 1985, no. 1, pp. $93-104$.

19. Korobeynikov A.F., Narseev V.A., Pshenichkin A.Ya., Revyakin P.S. Pirity zolotorudnykh mestorozhdeniy (svoystva, zonalnost, prakticheskoe znachenie) [Pyrites of gold fields (properties, zonality, practical value)]. Moscow, CNIGRI Publ., 1993. 213 p.

20. Pshenichkin A.Ya. Kristallomorfologiya pirita i ee ispolzovanie v praktike poiskovo-razvedochnykh rabot na zoloto [Pyrite crystal morphology and its use in the practice of exploration for gold]. Russian Geology and Geophysics, 1989, no. 11, pp. 65-75.

21. Bulynnikov A. Ya. Zolotorudnye formatsii i zolotonosnye provintsii Altae-Sayanskoy gornoy sistemy [Gold ore formations and gold-bearing provinces of the Altai-Sayan mountain system]. Trudy Tomskogo gosudarstvennogo universiteta, 1948, vol. 102, $299 \mathrm{p}$.

22. Korobeynikov A.F., Ananev Yu.S., Gusev A.I., Voroshilov V.G., Nomokonova G.G., Pshenichkin A.Ya., Timkin T.V. Rudno-metasomaticheskaya i geokhimicheskaya zonalnost zolotorudnykh poley i mestorozhdeniy skladchatykh poyasov Sibiri [Rudno-metaso- matic and geochemical zonation of gold ore fields and deposits of the folded belts of Siberia]. Ed. by A.F. Korobeynikov. Tomsk, TPU Publ., 2013. $458 \mathrm{p}$.

23. Voroshilov V.G., Ananev Yu.S. Ore-metasomatic and geochemical zonality of the Karatavsky gold ore occurrence (East Sayan). Bulletin of the Tomsk Polytechnic University, 2003, vol. 306, no. 1, pp. 33-38. In Rus.

24. Kuznetsov Yu.A. Glavnye tipy magmaticheskikh formatsy [The main types of igneous formations]. Moscow, Nedra Publ., 1964. $387 \mathrm{p}$.

25. Bezzubtsev V.V., Dyatlova I.N. Nekotorye problemy stratigrafii verkhnego rifeya-kembriya tsentralnoy chasti Sayano-Altayskoy skladchatoy oblasti (v svete usovershenstvovaniya seriynykh legend GDP-200/2) [Some problems of stratigraphy of the upper Riphean-Cambrian in the central part of the Sayano-Altai folded region (in the light of the improvement of the serial legends of the GDP-200/2)]. Available at: http://www.geologica.su/?p= 80\#more-80 (accessed 10 October 2018).

26. Polyakov G.V., Fedoseev G.S., Teleshev A.E., Nikolaev S.M. Shindinsky pluton Olkhovskogo granitoidnogo kompleksa (Vostochny Sayan) [Shinda Pluton of the Olkhovsky Granitoid Complex (Eastern Sayan)]. Magmaticheskie formatsii Altae-Sayanskoy skladchatoy oblasti [Magmatic formations of Altau-Sayan folded area]. Moscow, Nauka Publ., 1965. pp 84-111.

27. Korobeynikov A.F. Netraditsionnye kompleksnye zoloto-platinoidnye mestorozhdeniya skladchatykh poyasov [Non-traditional complex gold-platinoid deposits of folded belts]. Novosibirsk, SO RAN NIC OIGGM, 1999. $237 \mathrm{p}$.

28. Pshenichkin A.Ya. Termoelektricheskie svoystva piritov nekotorykh zolotorudnykh mestorozhdeniy razlichnykh tipov [Thermoelectric properties of pyrites of some gold ore deposits of various types]. Bulletin of the Tomsk Polytechnic Institute, 1977, vol. 247 , pp. $74-78$.

29. Pshenichkin A.Ya., Gavrilov R.Yu. Pyrites of the western flank of the Sukholozhsky gold ore field (Lena ore region). Bulletin of the Tomsk Polytechnic University. Geo Assets Engineering, 2018, vol. 329 , no. 5, pp. 74-78. In Rus.

30. Abdullaev G.K. K voprosu o morfologii kristallov pirita s usloviyami $\mathrm{k}$ obrazovaniya [0n the morphology of pyrite crystals with the conditions of their formation]. Doklady AN AzerbSSR, 1957, vol. 13 , no. 1, pp. 43-48.

31. Dzhafarov Ch.D. Kristallomorfologiya pirita i ee mineralogicheskoe znachenie [Crystallomorphology of pyrite and its mineralogical significance]. Baku, Elm. Publ., 1970. 118 p.

32. Pshenichkin A.Ya., Korobeynikov A.F., Matsyushevsky A.V. Osobennosti kristallomorfologii i termo-eds piritov zolotorudnykh mestorozhdeniy razlichnykh tipov [Features of a kristallomorfology and thermos-EMF of pyrites of gold fields of various types]. Bulletin of the Tomsk Polytechnic Institute, 1976, vol. 260 , pp. 39-48.

Received: 30 October 2018.

\section{Information about the authors}

Anatoliy Ya. Pshenichkin, Cand. Sc., head of the department, National Research Tomsk Polytechnic University.

Roman Yu. Gavrilov, Cand. Sc., associate professor, National Research Tomsk Polytechnic University. 